\title{
Synthesis of a new class of aminocyclitol analogues with the conduramine D-2 configuration
}

\author{
Latif Kelebekli, Yunus Kara ${ }^{*}$ and Murat Celik ${ }^{*}$
}

\section{Full Research Paper}

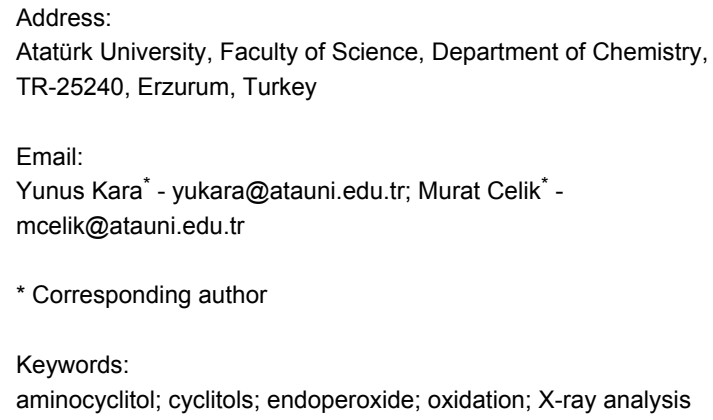

Beilstein Journal of Organic Chemistry 2010, 6, No. 15 doi:10.3762/bjoc.6.15

Received: 28 September 2009

Accepted: 07 February 2010

Published: 15 February 2010

Associate Editor: J. N. Johnston

(c) 2010 Kelebekli et al; licensee Beilstein-Institut.

License and terms: see end of document.

\begin{abstract}
A new class of aminocyclitol derivatives with the bicyclo[4.2.0]octane skeleton was synthesized starting from cyclooctatetraene. Photooxygenation of trans-7,8-diacetoxy- and cis-7,8-dichlorobicyclo[4.2.0]octa-2,4-diene afforded the bicyclic endoperoxides. Reduction of the latter with thiourea followed by a $\operatorname{Pd}(0)$ catalyzed ionization/cyclization reaction gave the corresponding oxazolidinone derivatives. Oxidation of the double bond with $\mathrm{KMnO}_{4}$ or $\mathrm{OsO}_{4}$ followed by acetylation gave the acetate derivatives, the exact configuration of which was determined by spectroscopic methods. Hydrolysis of the oxazolidinone rings and removal of the acetate groups furnished the desired aminocyclitols.
\end{abstract}

\section{Introduction}

Among the myriad of naturally occurring compounds are the aminocyclitol-containing natural products, which represent a large family of sugar derived microbial secondary metabolites and include the clinically active aminoglycoside inhibitors [1-11], many of which are widely used for the treatment of diseases in humans, animals and plants [1-15].

Glycosidase and related enzymes are involved in the biosynthesis of the oligosaccharide chains [1-15]. Carba analogues of oligosaccharides (carbasugars), generated by replacing the endocyclic O-atom in a monosaccharide [1-11], are thought to be better drug candidates than natural sugars, since they are hydrolytically stable. Spurred on by the heightened interest in

the design of carbohydrate mimetics, which can be potent inhibitors of glycosidase (1-4) [11-16], we have developed a method for rapid entry to these compounds.<smiles>NC1CC(CO)C(O)C(O)C1O</smiles><smiles>OC1C(O)C(O)C(Cl)C(Cl)C1O</smiles><smiles>NC1CC(O)C(O)C(O)C(O)C1</smiles>

2<smiles>OC1[C@H](O)[C@H]2[C@H]([C@H]1O)[C@@H](O)[C@@H]2O</smiles> 
Antibiotics containing an aminocyclitol unit have stimulated the development of synthetic methodologies [16] in the search for analogues with enhanced pharmacological profiles [6]. Balci and Kara [20-22] have synthesized the polyhydroxylated bicyclic molecule 5 having the bicyclo[4.2.0]octane skeleton bis-homoinositol. Furthermore, Trost et al. [23,24] have reported a regio- and stereoselective $\mathrm{Pd}(0)$ catalyzed reaction of diols in the presence of $p$-toluenesulfonyl isocyanate for the introduction of the amino alcohol functionality.

We are currently interested in the synthesis of cyclitols and their derivatives [25]. As a part of our program directed towards the synthesis of potential glycosidase inhibitors we used a bicyclo[4.2.0] octane framework for $\mathrm{OH}$, chlorine and $\mathrm{NH}_{2}$ groups as an intriguing carbohydrate alternative [26-30].

Herein, we report the synthesis of the new aminocyclitol analogues 6 and 7 from cyclooctatetraene.<smiles>O[C@@H]1[C@H](O)[C@H](O)[C@H]2[C@H]1[C@@H](O)[C@@H]2O</smiles>

6

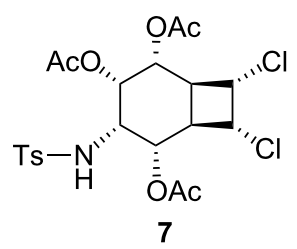

7

\section{Results and Discussion}

Diacetoxydiene 9 was synthesized in 99\% yield from cyclooctatetraene (8) by the addition of mercury(II) acetate [31]. Tetraphenylporphyrin sensitized photooxygenation of diacetoxydiene 9 with singlet oxygen gave the expected endoperoxide 10. Reduction of the peroxide bond in $\mathbf{1 0}$ was performed with thiourea under very mild conditions to give the cis-diol 11 in 99\% yield. The introduction of the amino alcohol functionality was achieved by a regio- and stereoselective $\operatorname{Pd}(0)$ catalyzed reaction of diol 11 and TsNCO [32]. Thus treatment of the cis-diol 11 in THF with 2 equiv of $p$-toluenesulfonyl isocyanate gave the corresponding bis-carbamate 12 which was subsequently added to a solution of $5 \mathrm{~mol} \%$ of the catalyst, prepared by stirring a mixture of ligand (triisopropylphosphite) and tris(dibenzylideneacetone)-dipalladium-chloroform complex in THF. Subsequent purification by column chromatography gave oxazolidinone $\mathbf{1 3}$ in $48 \%$ yield (Scheme 1). The structure of 13 was assigned by ${ }^{1} \mathrm{H}$ and ${ }^{13} \mathrm{C}$ NMR and later by $\mathrm{X}$-ray analysis of product $\mathbf{1 5}$.

The observed regio- and stereoselectivity was remarkable since the leaving groups are diastereotopic.

The metal-olefin complexation is a likely source of the stereoselectivity. Mechanistically, only palladium-olefin complexation anti to the leaving group will lead to the product 13 [33,34], which is inconsistent with a steric preference for the metal approaching the double bond in $\mathbf{1 2}$ from the side of the four-membered ring to form complex $\mathbf{1 4}$ (Scheme 2).

Since the double bond is not symmetrically disubstituted, palladium can theoretically form two complexes $\mathbf{1 5}$ and $\mathbf{1 6}$ after ionization. We assume that the formation of complex $\mathbf{1 5}$ is hindered due to the presence of an acetate group in the endo position.

cis-Dihydroxylation of $\mathbf{1 3}$ with $\mathrm{KMnO}_{4}$ at $-15{ }^{\circ} \mathrm{C}$ gave a single diol 17, which was converted into the tetraacetate by treatment with acetic anhydride/ $\mathrm{CH}_{3} \mathrm{COONa}$ [35] (Scheme 3). Careful examination of the reaction mixture did not reveal the formation of the other isomer. The stereochemical course of the hydroxylation may be syn or anti with respect to the oxazolidinone and cyclobutane rings. NMR spectroscopic

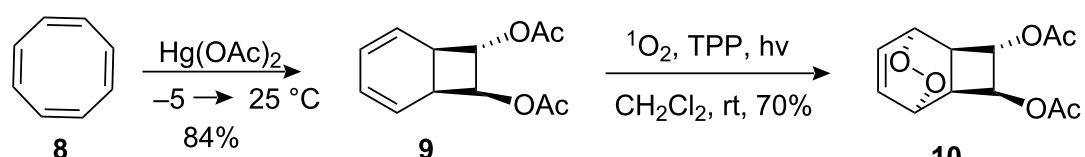
$84 \%$

8

9

10 $\downarrow \begin{aligned} & \text { Thiourea } \\ & \mathrm{MeOH}, \mathrm{rt}\end{aligned}$

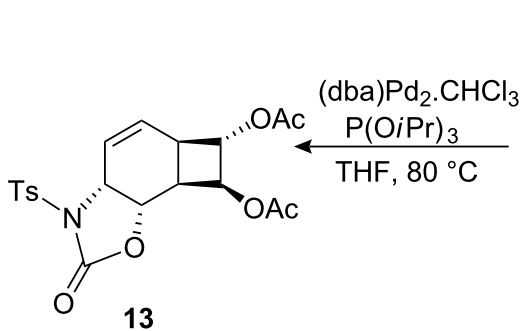

13

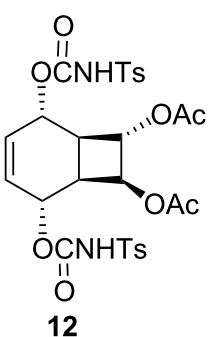

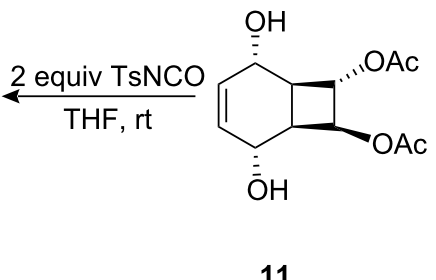




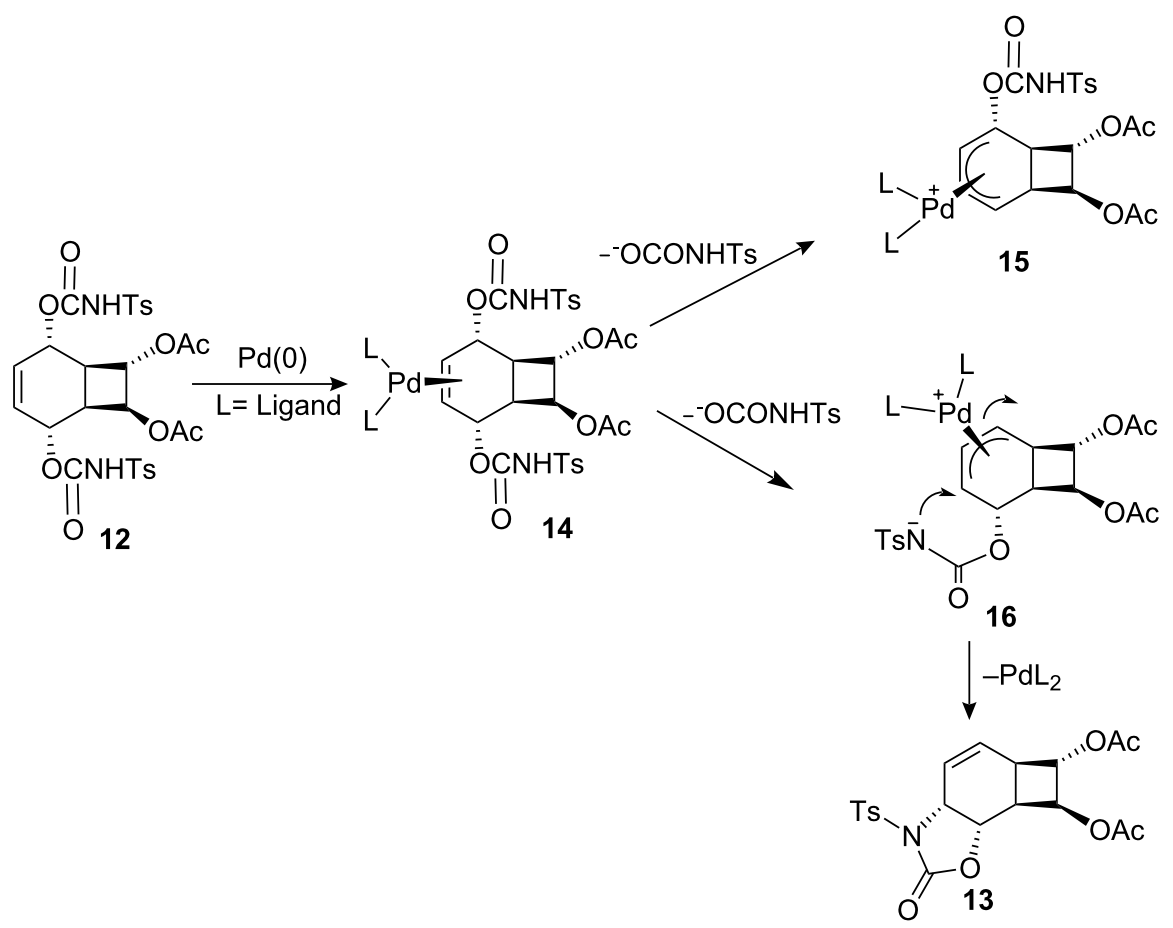

Scheme 2: Mechanism of the palladium-catalyzed ionization/cyclization reaction.

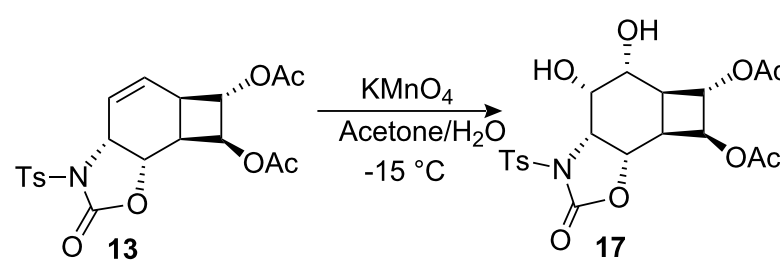

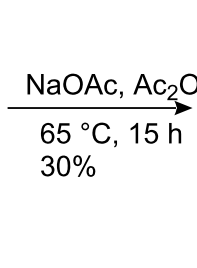

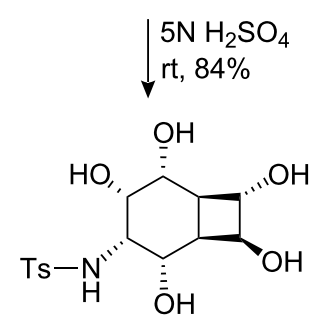

6

Scheme 3: Synthesis of aminocyclitol analogue 6.

studies did not allow the assignment of the exact orientation of the hydroxyl groups. X-ray analysis of $\mathbf{1 8}$ (Figure 1) revealed the exact configuration of the compound. This also confirms the configurations of endoperoxide 10, oxazolidinone 13 and cishydroxylation product 17 .

The all cis-configuration of the four acetate and amino groups in aminocyclitol 18 [25] attached to the six-membered ring resembles the configuration of conduramine D-2 [36-38]. Hydrolysis of the acetate groups with $\mathrm{H}_{2} \mathrm{SO}_{4}$ proceeded smoothly to deliver aminocyclitol 6 in $84 \%$ yield.

For the synthesis of dichloro derivative, we replaced the acetoxy groups in 9 with cis- configured chlorine atoms. This provides a route for the synthesis of other haloaminocyclitol derivatives. 


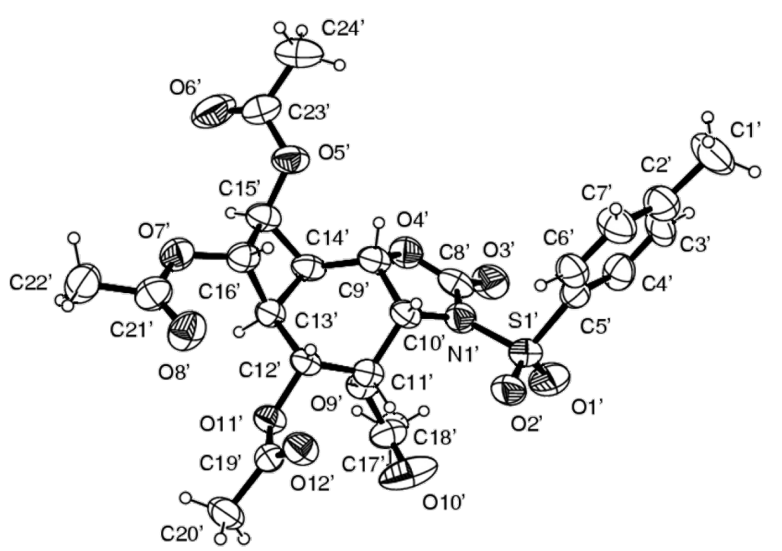

Figure 1: The thermal ellipsoid plot of the single crystal X-ray crystallographic structure of 18.

cis-Dichlorobicyclooctadiene $\mathbf{1 9}$ was synthesized from cyclooctatetraene 8 by the addition of chlorine following the literature procedure [39]. Photooxygenation of cis-dichlorobicylooctadiene 19 with singlet oxygen gave the expected endoperoxide 20 [19-21] (Scheme 4). Since the dichlorobicyclooctadiene 19 has no plane of symmetry, singlet oxygen approaches the diene unit exclusively from the less crowded side of the molecule in accord with previous reports [20,21]. Reduction of the peroxide bond in $\mathbf{2 0}$ with thiourea under very mild conditions gave the cis-diol 21 in 95\% yield. Diol 21 in THF was treated with 2 equiv of $p$-toluenesulfonyl isocyanate to give the intermediate bis-carbamate $\mathbf{2 2}$ which was then treated as described above for $\mathbf{1 2}$ with the same $\operatorname{Pd}(0)$ catalyst to afford, after chromatography on a silica gel with hexane/ethyl acetate (3:1) as eluant, the oxazolidinone $\mathbf{2 3}$ in $61 \%$ yield.

The structure of 23 was assigned by ${ }^{1} \mathrm{H}$ NMR and ${ }^{13} \mathrm{C}$ NMR spectroscopy. The double bond in $\mathbf{2 2}$ is symmetrically disubstituted, and therefore palladium can form only one complex $\mathbf{2 5}$ after ionization (Scheme 5).

Hydrolysis of oxazolidinone 23 with $\mathrm{K}_{2} \mathrm{CO}_{3}$ gave alcohol 26, which was subsequently converted into acetate 27 by treatment with $\mathrm{Ac}_{2} \mathrm{O} / \mathrm{NaOAc}$ [35] (Scheme 6).

cis-Hydroxylation of 27 with $\mathrm{OsO}_{4}$ at $0^{\circ} \mathrm{C}$ gave the corresponding diol 28, which was further converted into triacetate 7 with $\mathrm{Ac}_{2} \mathrm{O} / \mathrm{NaOAc}$ (Scheme 6). The exact configuration of triacetate 7 was confirmed by differential ${ }^{1} \mathrm{H}$ NMR NOE measurements<smiles>C1=CC=CC=CC=C1</smiles>

8<smiles>Cl[Mg]C(Cl)(Cl)Cl</smiles>

$75 \%$<smiles>C[C@@H]1C2C=CC=C[C@H]21</smiles>

19

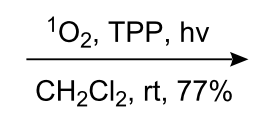<smiles>Cl[C@H]1[C@@H]2C3C=CC(OO3)[C@@H]1[C@H]2Cl</smiles>

20

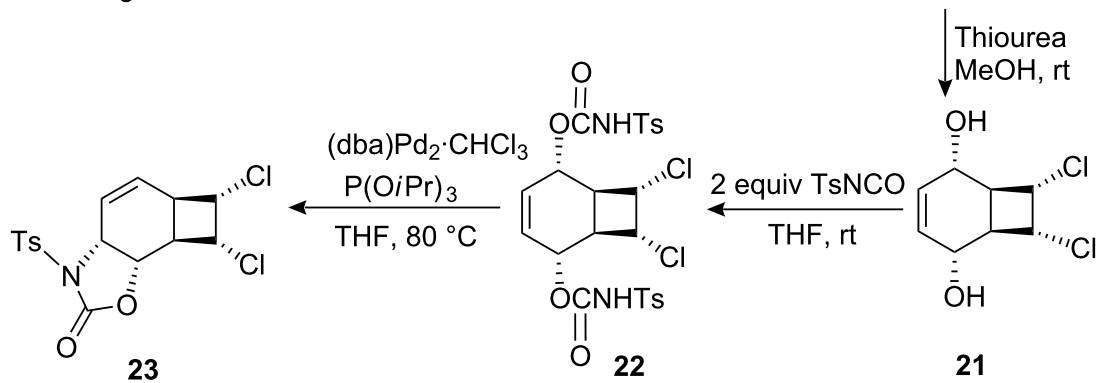

Scheme 4: Synthesis of oxazolidone 23.

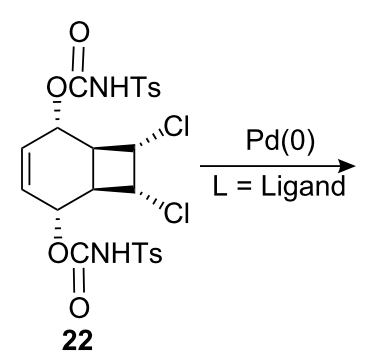

22

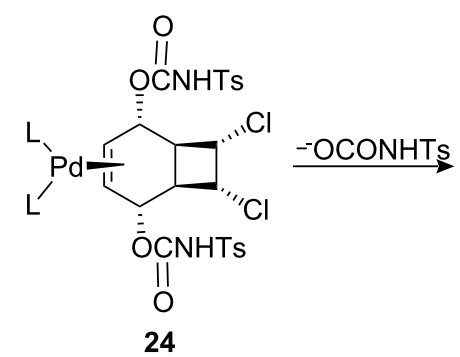

24

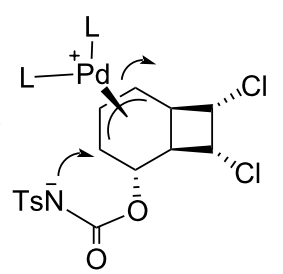

25<smiles>[13CH3]N1C(=O)O[C@@H]2C(Cl)C(Cl)C=C[C@@H]21</smiles>

23 


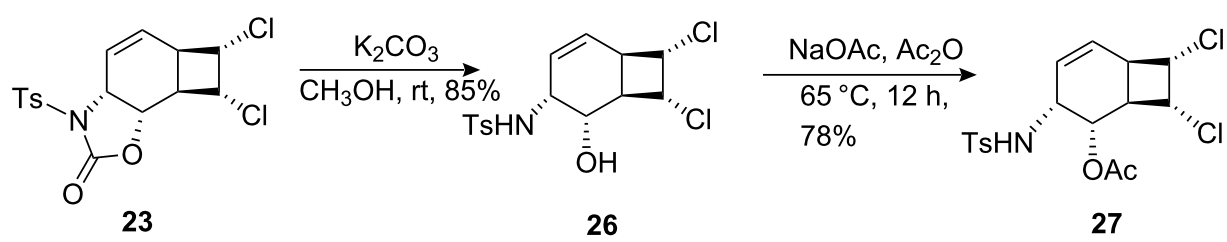

23

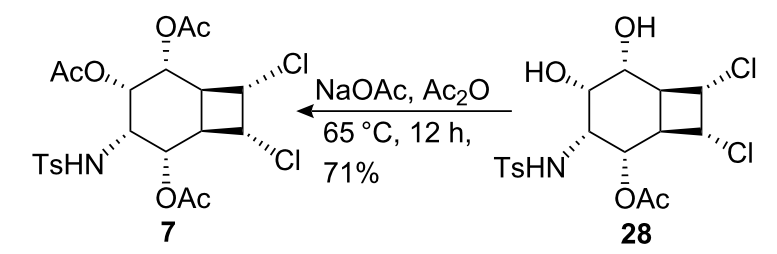

Scheme 6: Synthesis of dichloroaminocyclitol 7.

(Figure 2). Irradiation of $\mathrm{H}^{3}\left(\mathrm{H}^{3}-\mathrm{CNHTs}\right)$ at $\delta 3.85$ caused signal enhancements of $\mathrm{H}^{1}, \mathrm{H}^{2}$, and $\mathrm{H}^{4}$ at $\delta=5.45,5.28$ and 5.15 , respectively. This result is consistent with a cis-relationship between $\mathrm{H}^{1}, \mathrm{H}^{2}, \mathrm{H}^{3}$ and $\mathrm{H}^{4}$ protons.

We assume that the stereochemical course of the hydroxylation of $\mathbf{2 7}$ proceeds through syn addition as previously observed in the hydroxylation of $\mathbf{1 3}$, a quite similar structure to $\mathbf{2 7}$.

The all cis-configuration of the acetate and amino groups attached to the six-membered ring resembles the configuration of conduramine D-2 [31,40,41]. The cyclic polyhdroxylated amines, also known as aminocyclitols, possess a wide variety of biological activities [42-45]. In conclusion, we have outlined the synthesis of a new family of aminocyclitols analogues $\mathbf{6}$ and
7 based on the bicyclo[4.2.0]octane frame work, with stereocontrol during the formation of all the stereogenic centres.

\section{Experimental}

Melting points were determined on a Büchi 539 capillary melting apparatus and are uncorrected. Infrared spectra were obtained from $\mathrm{KBr}$ or film on a Mattson 1000 FT-IR spectrophotometer. The ${ }^{1} \mathrm{H}$ and ${ }^{13} \mathrm{C}$ NMR spectra were recorded on 200 (50) and 400 (100) $\mathrm{MHz}$ Varian spectrometer and are reported in $\delta$ units with $\mathrm{SiMe}_{4}$ as internal standard. Thin layer chromatography (TLC) was performed on E. Merck Silica Gel $60 \mathrm{~F}_{254}$ plate $(0.2 \mathrm{~mm})$. All column chromatography was performed on silica gel (60 mesh, Merck). Elemental analyses were carried out on a Carlo Erba 1108 model CHNS-O analyzer.

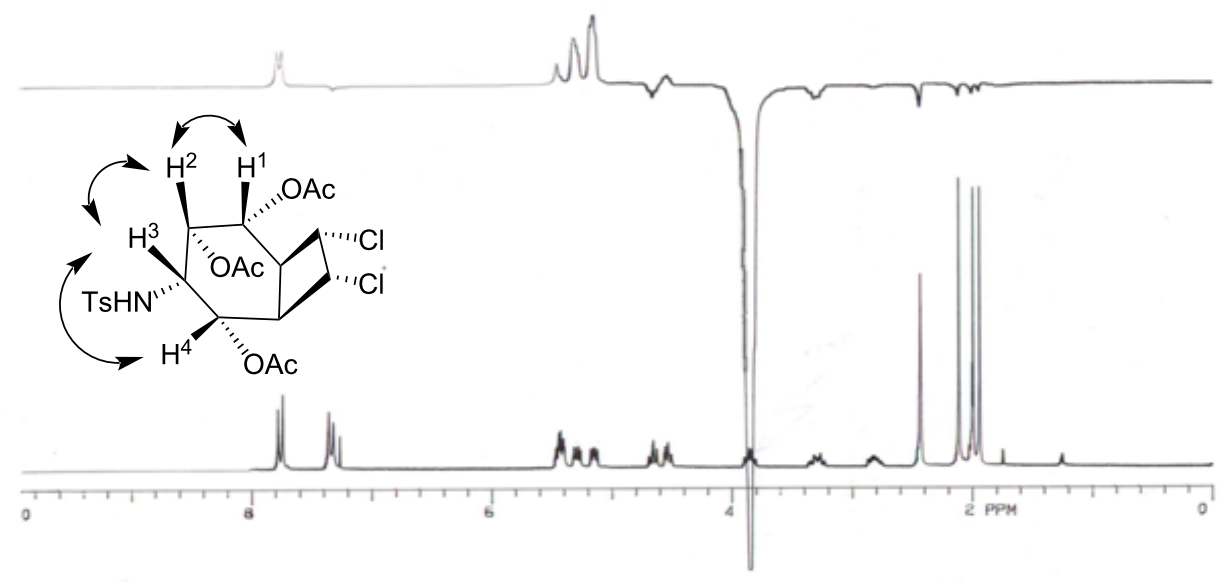

Figure 2: ${ }^{1} \mathrm{H}$ NMR NOE spectrum of compound 7. 


\section{Supporting Information}

\section{Supporting Information File 1}

Experimental Section

The experimental section describes the synthesis, purification and characterization data of all substances given in this article.

[http://www.beilstein-journals.org/bjoc/content/ supplementary/1860-5397-6-15-S1.pdf]

\section{Acknowledgements}

The authors are indebted to the Department of Chemistry (Atatürk University), state planning organization of Turkey (DPT) for purchasing a NMR, GS-MS and The Scientific and Technical Research Council of Turkey (TUBITAK, TBAG105T162).

\section{References}

1. Posternak, T. The Cyclitols; Holden Day: San Francisco, CA, 1962.

2. Anderson, L. The Cyclitols. In The Carbohydrates, 2nd ed.; Pigman, W.; Horton, D., Eds.; Academic Press: New York, 1972; Vol. 1A, pp 519-579.

3. Arjona, O.; Gómez, A. M.; López, C.; Plumet, J. Chem. Rev. 2007, 107, 1919. doi:10.1021/cr0203701

4. Asano, N. Glycobiology 2003, 13, 93R. doi:10.1093/glycob/cwg090

5. Heightman, T. D.; Vasella, A. T. Angew. Chem., Int. Ed. 1999, 38, 750. doi:10.1002/(SICI)1521-3773(19990315)38:6<750::AID-ANIE750>3.0. CO;2-6

6. Shan, M.; O'Doherty, G. A. Org. Lett. 2008, 10, 3381. doi:10.1021/ol801106r

7. Shan, M.; O'Doherty, G. A. Synthesis 2008, 19, 3171. doi:10.1055/s-2008-1067262

8. Chakraborty, C.; Vyavahare, V. P.; Dhavale, D. D. Tetrahedron 2007 63, 11984. doi:10.1016/j.tet.2007.09.011

9. Frigell, J.; Cumpstey, I. Tetrahedron Lett. 2007, 48, 9073. doi:10.1016/j.tetlet.2007.10.138

10. Sardinha, J.; Guieu, S.; Deleuze, A.; Fernández-Alonso, M. C.; Rauter, A. P.; Sinaÿ, P.; Marrot, J.; Jiménez-Babero, J.; Sollogoub, M. Carbohydr. Res. 2007, 342, 1689. doi:10.1016/j.carres.2007.05.021

11. Plumet, J.; Gomez, A. M.; Lopez, J. C. Mini-Rev. Org. Chem. 2007, 4, 201. doi:10.2174/157019307781369931

12. Chiasson, J.-L.; Josse, R. G.; Hunt, J. A.; Palmason, C.; Roger, N. W.; Ross, S. A.; Ryan, E. A.; Tan, M. H.; Wolever, T. M. S Ann. Intern. Med. 1994, 121, 928.

13. Balci, M. Pure Appl. Chem. 1997, 69, 97. doi:10.1351/pac199769010097

14. Hudlicky, T.; Reed, J. W. Advances in Asymmetric Synthesis; JAI Press: Greenwich, 1995; Vol. 1, p 271.

15. Carless, H. A. J. Tetrahedron: Asymmetry 1992, 3, 795. doi:10.1016/S0957-4166(00)82174-6

16. Gultekin, M. S.; Celik, M.; Balci, M. Curr. Org. Chem. 2004, 8, 1159. doi:10.2174/1385272043370069

17. El Ashry, E. S. H.; Rashed, N.; Shobier, A. H. S. Pharmazie 2000, 55, 251.
18. El Ashry, E. S. H.; Rashed, N.; Shobier, A. H. S. Pharmazie 2000, 55, 321.

19. El Ashry, E. S. H.; Rashed, N.; Shobier, A. H. S. Pharmazie 2000, 55, 403.

20. Kelebekli, L.; Kara, Y.; Balci, M. Carbohydr. Res. 2005, 340, 1940. doi:10.1016/j.carres.2005.05.021

21. Kara, Y.; Balci, M. Tetrahedron 2003, 59, 2063. doi:10.1016/S0040-4020(03)00209-6

22. Sahin, E.; Kelebekli, L.; Kara, Y.; Celik, M.; Balci, M. Acta Crystallogr. 2007, E63, o2464. doi:10.1107/S1600536807017011

23. Trost, B. M.; Van Vranken, D. L.; Birgel, C. J. Am. Chem. Soc. 1992, 114, 9327. doi:10.1021/ja00050a013

24. Trost, B. M.; Murphy, D. J. Organometallics 1985, 4, 1143. doi:10.1021/om00125a039

25. Kelebekli, L.; Celik, M.; Kara, Y.; Balci, M. Tetrahedron Lett. 2006, 47, 7031. doi:10.1016/j.tetlet.2006.07.108

26. Curti, C.; Zanardi, F.; Battistini, L.; Sartori, A.; Rassu, G.; Auzzas, L.; Roggio, A.; Pinna, L.; Casiraghi, G. J. Org. Chem. 2006, 71, 225. doi:10.1021/jo0520137

27. Contelles, Y.; de Opaza, E. J. Org. Chem. 2003, 67, 3705. doi:10.1021/jo0111107

28. Blériot, Y.; Giroult, A.; Mallet, J.-M.; Rodriguez, E.; Vogel, P.; Sinaÿ, P. Tetrahedron: Asymmetry 2002, 13, 2553. doi:10.1016/S0957-4166(02)00654-7

29. Honda, T.; Kimura, N. Org. Lett. 2002, 4, 4567. doi:10.1021/ol027192i

30. Boyer, F. D. J.; Lallemand, J.-Y. Synlett 1992, 969. doi:10.1055/s-1992-21548

31. Cope, A. C.; Nelson, N. A.; Smith, D. S. J. Am. Chem. Soc. 1954, 76, 1100. doi:10.1021/ja01633a049

32. Andriuzzi, O.; Gravier-Pelletier, C.; Vogel, P.; Le Merrer, Y. Tetrahedron 2005, 61, 7094. doi:10.1016/j.tet.2005.05.066

33. Trost, B. M.; Van Vranken, D. L. J. Am. Chem. Soc. 1993, 115, 444. doi:10.1021/ja00055a013

34. Trost, B. M.; Van Vranken, D. L. Chem. Rev. 1996, 96, 395. doi:10.1021/cr9409804

35. Celik, M.; Balci, M. ARKIVOC 2007, No. viii, 150.

36. Leung-Toung, R.; Liu, Y.; Muchowski, J. M.; Wu, Y.-L. Tetrahedron Lett. 1994, 35, 1639. doi:10.1016/0040-4039(94)88307-6

37. Leung-Toung, R. Y.; Liu, J.; Muchowski, J. M.; Wu, Y.-L. J. Org. Chem. 1998, 63, 3235. doi:10.1021/jo971907r

38. Supplementary data in the form of CIFs have been deposited with the Cambridge Crystallographic Data Centre (CCDC 299509). Copies of the data can be obtained, free of charge, on application to CCDC, 12 Union Road, Cambridge CB2 IEZ, UK [Fax: +44(0)-1223-336033 or e-mail: deposit@ccdc.cam.ac.uk]. Selected X-ray crystallographic data for $18\left(\mathrm{C}_{24} \mathrm{H}_{27} \mathrm{NO}_{12} \mathrm{~S}\right)$ : Space group: Orthorhombic, $P b n 21 ; a=$ 11.6906(4) $\AA, b=20.8899(10) \AA, c=22.1919(9) \AA, V=5419 \AA^{3}, Z=8$, $F(000)=2320, D_{\text {calc }}=1.36 \mathrm{~g} \mathrm{~cm}^{-3}, M_{0} K_{\alpha}=0.71073 \AA$, independent reflections 7705 (Rint $=0.0421), \lambda$ radiation observed reflections 7093 $(\mathrm{I}>2 \mathrm{rl}$ ), refinement method; full-matrix least-squares on $F 2$, data/restraints/parameters 7093/1/695, $R_{1}=0.0557, R_{\mathrm{w}}=0.1186$, goodness-of-fit on $F 2=1.21$.

39. Reppe, M.; Schlichting, O.; Klager, K.; Topel, T. Justus Liebigs Ann. Chem. 1948, 560, 1-92. doi:10.1002/jlac. 19485600102

40. Mehta, G.; Ramesh, S. S. Can. J. Chem. 2005, 83, 581. doi:10.1139/v05-032

41. Mehta, G.; Pavolli, K. Chem. Commun. 2002, 23, 2828. doi:10.1039/b208918a 
42. Lysek, R.; Vogel, P. Tetrahedron 2006, 62, 2733. doi:10.1016/j.tet.2005.11.046

43. Miyabe, H.; Nishiki, A.; Naito, T. Chem. Pharm. Bull. 2003, 51, 100. doi:10.1248/cpb.51.100

44. McIntosh, M. C.; Weinreb, S. M. J. Org. Chem. 1993, 58, 4823. doi:10.1021/jo00070a016

45. Secen, H.; Sütbeyaz, Y.; Balci, M. Tetrahedron 1990, 46, 3715. doi:10.1016/S0040-4020(01)90509-5

\section{License and Terms}

This is an Open Access article under the terms of the Creative Commons Attribution License

(http://creativecommons.org/licenses/by/2.0), which permits unrestricted use, distribution, and reproduction in any medium, provided the original work is properly cited.

The license is subject to the Beilstein Journal of Organic Chemistry terms and conditions:

(http://www.beilstein-journals.org/bjoc)

The definitive version of this article is the electronic one which can be found at: doi:10.3762/bjoc. 6.15 